\title{
To operate, or not to operate? Narrative review of the role of survival predictors in patient selection for operative management of patients with metastatic spine disease
}

\author{
Zach Pennington, BS, Jeff Ehresman, BS, Ethan Cottrill, MS, Daniel Lubelski, MD, \\ Kurt Lehner, MD, James Feghali, MD, A. Karim Ahmed, MD, Andrew Schilling, BA, and \\ Daniel M. Sciubba, MD
}

Department of Neurosurgery, Johns Hopkins University School of Medicine, Baltimore, Maryland

\begin{abstract}
Accurate prediction of patient survival is an essential component of the preoperative evaluation of patients with spinal metastases. Over the past quarter of a century, a number of predictors have been developed, although none have been accurate enough to be instituted as a staple of clinical practice. However, recently more comprehensive survival calculators have been published that make use of larger data sets and machine learning to predict postoperative survival among patients with spine metastases. Given the glut of calculators that have been published, the authors sought to perform a narrative review of the current literature, highlighting existing calculators along with the strengths and weaknesses of each. In doing so, they identify two "generations" of scoring systems-a first generation based on a priori factor weighting and a second generation comprising predictive tools that are developed using advanced statistical modeling and are focused on clinical deployment. In spite of recent advances, the authors found that most predictors have only a moderate ability to explain variation in patient survival. Second-generation models have a greater prognostic accuracy relative to first-generation scoring systems, but most still require external validation. Given this, it seems that there are two outstanding goals for these survival predictors, foremost being external validation of current calculators in multicenter prospective cohorts, as the majority have been developed from, and internally validated within, the same single-institution data sets. Lastly, current predictors should be modified to incorporate advances in targeted systemic therapy and radiotherapy, which have been heretofore largely ignored.
\end{abstract}

https://thejns.org/doi/abs/10.3171/2020.6.SPINE20707

KEYWORDS spinal metastases; survival prediction; predictive analytics; quality of life; minimally invasive surgery; patient selection; oncology

$\mathrm{O}$ NE million Americans are currently living with metastatic spine disease, ${ }^{1}$ but only a minority are symptomatic. Five percent to ten percent of patients develop epidural spinal cord compression (ESCC), $)^{2,3}$ and many suffer from debilitating mechanical pain. ${ }^{4}$ These patients likely derive symptomatic benefit from surgical intervention ${ }^{5,6}$ that lasts up to 2 years postoperatively. ${ }^{7,8}$

Often these patients may be poor surgical candidates or may not live long enough to see the benefits of surgery.9,10 Expected survival has long been a driver of surgical candidacy, and thus multiple prior studies have focused on identifying prognosis and expected survival. ${ }^{11}$ Survival predictors have been described for this population ${ }^{12}$ to aid in the decision-making process..$^{13}$ More recently, detailed prediction tools have been developed that incorporate multiple patient-specific variables to determine a patient's expected outcome..$^{14,15}$ The most successful clinical tools used in the spine metastasis population are the Spinal Instability Neoplastic Score ${ }^{4}$ and the $\mathrm{ESCC}^{16}$ scale, which have made it into use in clinical trials (e.g., NCT02830451, clinicaltrials. gov). Both have been shown to have good clinical interrater reliability ${ }^{16,17}$ as well as to successfully identify patients who experience symptomatic benefit from surgical intervention. ${ }^{18-20}$ However, both of these tools were designed as scoring systems that could create a common language for describing a patient's spinal metastasis, as opposed to

ABBREVIATIONS AUC = area under the curve; ECOG = Eastern Cooperative Oncology Group; ESCC = epidural spinal cord compression; GSTSG = Global Spine Tumour Study Group; KPS = Karnofsky Performance Status; NESMS = New England Spinal Metastasis Score; NSQIP = National Surgical Quality Improvement Program; $\mathrm{PPV}=$ positive predictive value; $\mathrm{QOL}=$ quality of life; SORG = Skeletal Oncology Research Group.

SUBMITTED April 28, 2020. ACCEPTED June 1, 2020.

INCLUDE WHEN CITING Published online September 11, 2020; DOI: 10.3171/2020.6.SPINE20707. 
functioning as an outcome predictor. Additionally, neither describes the odds of postoperative survival.

The development of an accurate predictor of postoperative survival therefore remains an ongoing process. In the present review, we provide an overview of the development and utility of these tools and highlight current research that aims to use machine learning and multicenter collaborations to develop highly predictive, clinically valuable tools. We complete the review by discussing current investigations that call into question whether survival should serve as the basis for surgical candidacy.

\section{Survival Predictors}

Operative management of spine metastases has relatively high complication rates, ${ }^{21,22}$ which may be due in part to the frailty of this patient population..$^{23}$ These complications delay discharge and prolong a patient's path to recovery, in some cases to the point where they may not survive long enough to experience the benefits of surgery. Consequently, a major focus of spinal oncology research over the past 2 decades has been identifying predictors of postoperative survival. ${ }^{24}$

Multiple reviews of predictors of postoperative survival have been performed. One recent review by Luksanapruksa et al. ${ }^{12}$ included a quantitative meta-analysis of 43 studies and more than 13,000 patients. They identified poor prognostic factors to include preoperative neurological deficit; the presence of visceral, multiple spine, or multiple bone metastases; poor Karnofsky Performance Status (KPS); poor Eastern Cooperative Oncology Group (ECOG) grade; and aggressive primary tumor pathology. Similar factors have been identified in other recent reviews. ${ }^{25,26}$ More recent studies have suggested that patients with spinal metastases should be treated similarly to other patients with terminal or end-stage disease. These papers have found that survival is best predicted by measures of physical reserve, with poorer survival being observed among patients who are frail,,$^{23}$ sarcopenic, ${ }^{27}$ or cachectic. ${ }^{24}$

\section{Early Scoring Systems \\ Postoperative Survival Predictors}

The most widely used survival scales are the system of Tomita et al. ${ }^{28}$ and the revised system of Tokuhashi et al. ${ }^{29}$ (Table 1). The original Tokuhashi score was first published in the English-language literature in 1990 based on a cohort of 64 surgically treated patients with vertebral body collapse. Patients were scored according to 6 factors: 1) baseline KPS; 2) number of extraspinal bone metastases; 3) number of vertebral body metastases; 4) metastatic involvement of the major internal organs; 5) primary pathology; and 6) Frankel score (called "spinal cord palsy"). The authors demonstrated that an increasing score correlated with a higher mean postoperative survival and recommended that patients with a score of $\leq 5$ (out of 12) be treated nonsurgically. However, they did not examine the ability of the score to predict survival at any specific time point (e.g., 3 months) that might be used in the surgical decision-making process. Additionally, they did not externally validate the score, making it unclear whether it would be an effective survival predictor in other populations. Tokuhashi et al..$^{30}$ subsequently updated their scoring system using a population of 246 patients by expanding the pathology domain to include additional primary tumor types. The revised system better modeled postoperative survival, with a score of $\leq 8$ having a sensitivity and specificity for survival at 6 months of $88.1 \%$ and $75.8 \%$, respectively. This updated score was then recommended as a clinical tool by the Global Spine Tumour Study Group (GSTSG), along with the Tomita score ${ }^{31}$ Since the GSTSG recommendation, the score has undergone another revision by Morgen and colleagues, who removed the extraspinal bony metastasis component. ${ }^{32}$ In their mixed cohort of 1143 surgical or conservatively managed patients, Morgen et al. found that their updated score better predicted survival at both 6 months and 12 months.

The Tomita system ${ }^{28}$ - the other system recommended by the GSTSG ${ }^{31}$-was published in 2001 based on a set of 67 patients treated at a single center. Patients are scored according to their primary tumor pathology (categorized as slow, moderate, or rapid growth), the presence of visceral metastases, and the extent of osseous metastases. Scores range from 2 to 10 , with lower scores indicating better prognosis and supporting more aggressive surgical intervention with the goal of local control. While relatively straightforward, the scale is relatively subjective, given the need to categorize the primary tumor growth rate and the treatability of visceral metastases. Nevertheless, the original authors validated it in a second population of 61 patients. ${ }^{28}$ They did not, however, examine its ability to predict survival to a predetermined time point (e.g., 3 months), which limits its ability to be used as a decisionmaking tool by surgeons who use expected survival for determining surgical candidacy. Additionally, like the Tokuhashi score, the Tomita system was developed prior to the widespread availability of many modern therapeutic options, including radiofrequency ablation and stereotactic radiosurgery. The treatment prescriptions advised by these scoring systems (e.g., the Tomita score advising en bloc resection for patients with a score of 2-4) may not be applicable to modern patient populations.

The Sioutos scoring system was published in 1995 based on a series of 109 patients with thoracic spine metastases who underwent surgical decompression for ESCC. ${ }^{33}$ Patients are assigned a score from 0 to 3 based on primary pathology, preoperative ambulatory function, and the number of vertebral body metastases. Sioutos et al. showed that the score correlates with median survival. Similar to prior studies, however, the authors did not provide data correlating score with probability of survival at any of the time points conventionally used to determine surgical candidacy (e.g., 3 months or 6 months). Consequently, it may have limited utility in the clinical setting.

\section{Nonsurgical Predictors}

The Rades system ${ }^{34}$ differs from prior scoring systems in that it is derived from a large, nonsurgical cohort of patients receiving radiotherapy for ESCC. The score is based on 6 factors shown to correlate with survival in the original cohort: 1) primary pathology; 2) the presence of multiple 
TABLE 1. Early predictor scales

\begin{tabular}{|c|c|c|c|c|}
\hline $\begin{array}{l}\text { Scoring } \\
\text { System }\end{array}$ & $\begin{array}{l}\text { Authors } \\
\text { \& Year }\end{array}$ & Population & Predictors & Diagnostic Properties \\
\hline \multirow{7}{*}{ Tokuhashi } & \multirow{7}{*}{$\begin{array}{l}\text { Tokuhashi } \\
\text { et al., } \\
\text { 199029 }\end{array}$} & $\begin{array}{l}\text { Single-center cohort of } 64 \text { surgically } \\
\text { treated pts w/ spinal metastases }\end{array}$ & Primary tumor & $\begin{array}{l}\text { Correlation btwn survival \& score } \\
\text { of } 0.6547\end{array}$ \\
\hline & & & KPS: $10-40 / 50-70 / 80-100$ & No external validation done \\
\hline & & & No. of extraspinal bone metastases & \\
\hline & & & No. of VB metastases & \\
\hline & & & $\begin{array}{l}\text { Spinal cord injury: complete, incomplete, } \\
\text { or none }\end{array}$ & \\
\hline & & & $\begin{array}{l}\text { Visceral metastases: none, removable, } \\
\text { unremovable }\end{array}$ & \\
\hline & & & $\begin{array}{l}\text { Score } 0-12 \text {; higher score portends better } \\
\text { survival }\end{array}$ & \\
\hline \multirow{7}{*}{$\begin{array}{l}\text { Revised } \\
\text { Tokuhashi }\end{array}$} & \multirow{7}{*}{$\begin{array}{l}\text { Tokuhashi } \\
\text { et al., } \\
2005^{30}\end{array}$} & $\begin{array}{l}\text { Single-center cohort of } 246 \mathrm{pts} \text { w/ } \\
\text { spinal metastases managed w/ } \\
\text { surgical or medical management }\end{array}$ & Primary tumor & Correlation w/ survival: \\
\hline & & & KPS: $10-40 / 50-70 / 80-100$ & $r=0.61$ for excisional surgery group \\
\hline & & & $\begin{array}{l}\text { No. of extraspinal bone metastases: } 0 \text { vs } \\
1-2 \text { vs } \geq 3\end{array}$ & $r=0.53$ for palliative surgery group \\
\hline & & & No. of VB metastases: 1 vs 2 vs $\geq 3$ & $r=0.62$ for conservative Tx group \\
\hline & & & Frankel score: A/B, C/D, E & $\begin{array}{l}\text { Score } \leq 8: \mathrm{Sn}=88.1 \% ; \mathrm{Sp}=75.8 \% \\
\text { PPV }=85.2 \% ; \mathrm{NPV}=80 \% \text { for } \\
\text { death w/in } 6 \text { mos }\end{array}$ \\
\hline & & & $\begin{array}{l}\text { Visceral metastases: none, removable, } \\
\text { unremovable }\end{array}$ & \\
\hline & & & $\begin{array}{l}\text { Score } 0-15 \text {; higher score portends better } \\
\text { survival }\end{array}$ & \\
\hline \multirow{6}{*}{$\begin{array}{l}\text { Morgen } \\
\text { modification } \\
\text { to Tokuhashi }\end{array}$} & \multirow{6}{*}{$\begin{array}{l}\text { Morgen } \\
\text { et al., } \\
2018^{32}\end{array}$} & $\begin{array}{l}\text { Singe-center cohort of } 1143 \text { pts w/ } \\
\text { spinal metastases who under- } \\
\text { went surgical }(n=165) \text { or conser- } \\
\text { vative }(n=978) \text { management }\end{array}$ & Primary tumor & AUC: 0.71 at 6 mos; 0.72 at $1 \mathrm{yr}$ \\
\hline & & & KPS: $10-40 / 50-70 / 80-100$ & \\
\hline & & & No. of VB metastases: 1 vs 2 vs $\geq 3$ & \\
\hline & & & $\begin{array}{l}\text { Visceral metastases: none, removable, } \\
\text { unremovable }\end{array}$ & \\
\hline & & & Frankel score: $A / B, C / D, E$ & \\
\hline & & & $\begin{array}{l}\text { Score } 0-12 \text {; higher score portends better } \\
\text { survival }\end{array}$ & \\
\hline \multirow{4}{*}{ Sioutos } & \multirow{4}{*}{$\begin{array}{l}\text { Sioutos } \\
\text { et al., } \\
1995^{33}\end{array}$} & $\begin{array}{l}109 \text { surgically treated pts w/ thoracic } \\
\text { spine metastases causing cord } \\
\text { compression }\end{array}$ & $\begin{array}{l}\text { Primary pathology: lung vs breast vs colon } \\
\text { vs prostate vs renal cell vs other }\end{array}$ & No defined endpoint for survival \\
\hline & & & Preop ambulatory status: yes vs no & \\
\hline & & & No. of thoracic VBs involved: 1 vs $\geq 1$ & \\
\hline & & & $\begin{array}{l}\text { Score } 0-3 \text {; lower score portends better } \\
\text { survival }\end{array}$ & \\
\hline
\end{tabular}

skeletal metastases; 3) the presence of visceral metastases; 4) the length of time between tumor diagnosis and occurrence of ESCC; 5) pretreatment ambulatory function; and 6 ) increased time between the development of motor deficits and initiation of radiotherapy. Scores range from 20 to 45 , with higher scores portending improved survival. Post hoc analysis of their results shows that using a threshold score of $\geq 36$ gives sensitivities of $76.5 \%$ and $93.2 \%$ for survival at 6 months and 1 year, respectively. The positive predictive values (PPVs) at these time points were $93.4 \%$ and $75.3 \%$, respectively. This scoring system is limited by the inclusion of a nonsurgical cohort, however. Patients 
» CONTINUED FROM PAGE 137

TABLE 1. Early predictor scales

\begin{tabular}{|c|c|c|c|c|}
\hline $\begin{array}{l}\text { Scoring } \\
\text { System }\end{array}$ & $\begin{array}{l}\text { Authors } \\
\& \text { Year }\end{array}$ & Population & Predictors & Diagnostic Properties \\
\hline \multirow{5}{*}{ Bauer } & \multirow{5}{*}{$\begin{array}{l}\text { Bauer \& } \\
\text { Wedin, } \\
1995^{37}\end{array}$} & $\begin{array}{l}\text { Single-center cohort of } 241 \text { pts w/ } \\
\text { osseous metastases }(n=88 \mathrm{w} / \\
\text { spinal metastases) }\end{array}$ & Pathologic fracture & $\begin{array}{l}\text { Score } \geq 4 \text { : PPV }=50 \% \text { for survival } \\
\text { beyond } 1 \mathrm{yr}\end{array}$ \\
\hline & & $\begin{array}{l}\text { 76/88 spine metastasis pts under- } \\
\text { went surgery for epidural disease }\end{array}$ & Presence of visceral or brain metastases & $\begin{array}{l}\text { Score } \leq 1: \text { PPV }=100 \% \text { for death } \\
\text { w/in } 6 \text { mos }\end{array}$ \\
\hline & & & $\begin{array}{l}\text { Primary pathology: lung vs breast vs kid- } \\
\text { ney vs myeloma/lymphoma vs other }\end{array}$ & \\
\hline & & & Solitary vs multiple skeletal metastases & \\
\hline & & & $\begin{array}{l}\text { Scored by no. of criteria fulfilled }(0-5) \\
\text { higher score portends better survival }\end{array}$ & \\
\hline \multirow{4}{*}{$\begin{array}{l}\text { Modification } \\
\text { to Bauer }\end{array}$} & \multirow{4}{*}{$\begin{array}{l}\text { Leithner } \\
\text { et al., } \\
2008^{38}\end{array}$} & $\begin{array}{l}\text { Single-center cohort of } 69 \text { pts who } \\
\text { underwent surgical management } \\
\text { of spine metastases }\end{array}$ & Presence of visceral or brain metastases & $\begin{array}{l}\text { Found to be better at predicting } \\
\text { survival than original Bauer; no } \\
\text { testing of diagnostic accuracy }\end{array}$ \\
\hline & & & $\begin{array}{l}\text { Primary pathology: lung vs breast vs kid- } \\
\text { ney vs myeloma/lymphoma vs other }\end{array}$ & \\
\hline & & & Solitary vs multiple skeletal metastases & \\
\hline & & & $\begin{array}{l}\text { Scored by no. of criteria fulfilled }(0-4) \\
\text { higher score portends better survival }\end{array}$ & \\
\hline \multirow{4}{*}{ Tomita } & \multirow{4}{*}{$\begin{array}{l}\text { Tomita } \\
\text { et al., } \\
2001^{28}\end{array}$} & $\begin{array}{l}\text { Single-center cohort of } 67 \mathrm{pts} \text { w/ } \\
\text { spinal metastases }\end{array}$ & $\begin{array}{l}\text { Primary tumor pathology/growth rate: slow, } \\
\text { moderate, or rapid growth }\end{array}$ & $\begin{array}{l}\text { Correlation w/ survival is }-0.690 \text { in } \\
\text { training cohort }\end{array}$ \\
\hline & & $\begin{array}{l}\text { Validated in } 2 \text { nd population of } 61 \\
\text { surgically treated pts }\end{array}$ & $\begin{array}{l}\text { Visceral metastases: none, treatable, } \\
\text { untreatable }\end{array}$ & No external validation done \\
\hline & & & Bone metastases: none, $1, \geq 2$ & \\
\hline & & & $\begin{array}{l}\text { Pts slotted into Tx goal \& surgical strategy } \\
\text { groups based on total score }(2-10) \\
\text { lower score portends better survival }\end{array}$ & \\
\hline \multirow{6}{*}{ Katagiri } & \multirow{6}{*}{$\begin{array}{l}\text { Katagiri } \\
\text { et al., } \\
2005^{39}\end{array}$} & $\begin{array}{l}\text { Single-center cohort of } 350 \text { pts } \\
\text { surgically or nonsurgically treated } \\
\text { for skeletal metastases }\end{array}$ & $\begin{array}{l}\text { Primary pathology: hepatocellular, lung, or } \\
\text { GI carcinoma vs hematologic or breast, } \\
\text { prostate, or thyroid carcinoma vs other }\end{array}$ & $\begin{array}{c}\text { Score } \leq 2: \mathrm{Sn}=97.9 \% \text { at } 6 \text { mos, } \\
89.1 \% \text { at } 1 \mathrm{yr}, 75.3 \% \text { at } 2 \mathrm{yrs}\end{array}$ \\
\hline & & $\begin{array}{l}101 \text { pts treated w/ surgery ( } 37 \text { for } \\
\text { spinal metastases) }\end{array}$ & ECOG status: $3-4$ vs $0-2$ & $\begin{array}{l}\text { Score } \geq 6 \text { : } S n=68.7 \% \text { for }<6 \text { mos, } \\
89.1 \% \text { for }<1 \mathrm{yr}, 97.7 \% \text { for }<2 \text { yrs }\end{array}$ \\
\hline & & & Prior chemotherapy: yes/no & \\
\hline & & & $\begin{array}{l}\text { Presence of visceral or brain metastases: } \\
\text { yes/no }\end{array}$ & \\
\hline & & & Presence of multiple skeletal metastases & \\
\hline & & & $\begin{array}{l}\text { Score } 0-8 \text {; lower score portends better } \\
\text { survival }\end{array}$ & \\
\hline \multirow{4}{*}{ Van der Linden } & \multirow{4}{*}{$\begin{array}{l}\text { Van der } \\
\text { Linden } \\
\text { et al., } \\
2005^{35}\end{array}$} & $\begin{array}{l}\text { Subset of } 342 \text { pts w/ spine metasta- } \\
\text { ses derived from larger (cohort of } \\
1157 \text { pts), multicenter, random- } \\
\text { ized controlled trial of radiothera- } \\
\text { py for bony metastases }\end{array}$ & KPS: $10-40$ vs $50-70$ vs $80-100$ & No defined endpoint for survival \\
\hline & & & $\begin{array}{l}\text { Primary pathology: lung vs prostate vs } \\
\text { breast vs other }\end{array}$ & \\
\hline & & & Presence of visceral metastases: yes vs no & \\
\hline & & & $\begin{array}{l}\text { Score } 0-6 \text {; higher score portends better } \\
\text { survival }\end{array}$ & \\
\hline
\end{tabular}


» CONTINUED FROM PAGE 138

TABLE 1. Early predictor scales

\begin{tabular}{|c|c|c|c|c|}
\hline $\begin{array}{l}\text { Scoring } \\
\text { System }\end{array}$ & $\begin{array}{l}\text { Authors } \\
\& \text { Year }\end{array}$ & Population & Predictors & Diagnostic Properties \\
\hline \multirow{7}{*}{ Rades } & \multirow{7}{*}{$\begin{array}{l}\text { Rades } \\
\qquad \text { et al., } \\
2008^{34}\end{array}$} & $\begin{array}{l}\text { Single-center cohort of } 1852 \mathrm{pts} \\
\text { treated w/ radiotherapy for ESCC }\end{array}$ & $\begin{array}{l}\text { Primary tumor: breast vs prostate vs } \\
\text { hematologic vs lung vs other }\end{array}$ & Score $\geq 36$ : \\
\hline & & & $\begin{array}{l}\text { Time btwn tumor diagnosis \& ESCC: } \leq 15 \\
\text { vs }>15 \text { mos }\end{array}$ & $\begin{array}{l}\geq 6 \text { mos: } S n=76.5 \% ; \text { Sp }=93.1 \% \\
\quad \text { PPV }=93.4 \% ; \text { NPV }=75.6 \%\end{array}$ \\
\hline & & & $\begin{array}{l}\text { Presence of multiple skeletal metastases: } \\
\text { yes vs no }\end{array}$ & $\begin{array}{c}\geq 1 \text { yr: } S n=93.2 \% ; S p=82.0 \% \\
\quad P P V=75.3 \% ; N P V=95.3 \%\end{array}$ \\
\hline & & & Presence of visceral metastases: yes vs no & \\
\hline & & & Pre-Tx ambulatory function: yes vs no & \\
\hline & & & $\begin{array}{l}\text { Time btwn onset of motor dysfunction \& Tx: } \\
\leq 14 \text { vs }>14 \text { days }\end{array}$ & \\
\hline & & & $\begin{array}{l}\text { Score } 20-45 \text {; higher score portends better } \\
\text { survival }\end{array}$ & \\
\hline \multirow{5}{*}{ OSRI } & \multirow{5}{*}{$\begin{array}{l}\text { Balain } \\
\text { et al., } \\
2013^{36}\end{array}$} & $\begin{array}{l}\text { Single-center cohort of } 199 \text { pts } \\
\text { treated w/ surgery \&/or radio- } \\
\text { therapy for spinal metastases; } n \\
\text { = } 104 \text { treated w/ surgery }\end{array}$ & $\begin{array}{l}\text { PTP: slow vs moderate vs rapid vs very } \\
\text { rapid growth }\end{array}$ & $\begin{array}{l}\text { Concordance btwn expected \& pre- } \\
\text { dicted survival }=0.67 ; R^{2}=0.28\end{array}$ \\
\hline & & & GC: KPS $10-40$ vs $50-70$ vs $80-100$ & Score $=1$ \\
\hline & & & Scoring: OSRI = PTP + (2 - GC) & $\begin{aligned} \geq 1 \text { yr: } S n=45.6 \% ; S p=87.8 \% \\
\quad P P V=66.0 \% ; \text { NPV }=75.7 \%\end{aligned}$ \\
\hline & & & $\begin{array}{l}\text { Score } 0-7 \text {; lower score portends better } \\
\text { survival }\end{array}$ & Score $\leq 2$ \\
\hline & & & & $\begin{array}{l}\geq 1 \text { yr: } S n=89.7 \% ; S p=48.1 \% \\
\quad P P V=47.3 \% ; N P V=90 \%\end{array}$ \\
\hline
\end{tabular}

$\mathrm{GC}=$ general condition; $\mathrm{GI}$ = gastrointestinal; NPV = negative predictive value; $\mathrm{OSRI}=$ Oswestry Spinal Risk Index; $p t$ = patient; PTP = primary tumor pathology; $\mathrm{Sn}=$ sensitivity; $\mathrm{Sp}=$ specificity; Tx = treatment; VB = vertebral body.

in the nonsurgical population may have different overall prognoses, systemic burdens of disease, and medical comorbidities that otherwise bar them from surgical candidacy. Consequently, it is unclear if the sensitivity and specificity of the test would be similar in a surgical cohort.

Van der Linden et al. ${ }^{35}$ reviewed 342 patients with spinal metastases who formed a subset of a larger, multicenter, randomized trial of radiotherapy for bone metastases. They identified survival to be best predicted by primary pathology, the presence of visceral metastases, and the patient's baseline KPS. Using a scale of $0-6$, higher scores were found to portend better survival. However, the scale was limited by the lack of a defined survival endpoint and the use of a nonsurgical population. As previously stated, a nonsurgical cohort may be sicker overall than a surgical population, making it unclear if the scale is truly generalizable to all patients with spine metastases. Similarly, by not examining survival to a given endpoint, it is unclear how the scoring system would give a clinically useful prognosis (e.g., survival at 3 months) that could be used by surgeons to determine surgical candidacy.

Most recently, Balain et al. ${ }^{36}$ described the Oswestry Risk Index in a single-institution cohort of 199 patients treated with surgery and/or radiotherapy. The score comprises only primary pathology and KPS and was found to predict survival with $67 \%$ accuracy, as defined by the degree of concordance between predicted and observed survival. Examination of the original data shows that a risk index of 1 has a high specificity (87.8\%) and moderate negative predictive value (75.7\%) for survival beyond 1 year.

\section{Scores for All Bony Metastases}

Although not specific to the spinal metastasis population, there are three scoring systems $\mathrm{s}^{37-39}$ that have previously been demonstrated to have moderate predictive accuracy within the spinal metastasis population. ${ }^{14,40}$ The Bauer score ${ }^{37}$ was developed shortly after the original Tokuhashi score using a population of 241 patients with osseous metastases, of whom 88 had spinal metastases. All patients were examined as a single group using multivariate analysis, which demonstrated the presence of a pathologic fracture, visceral or brain metastases, lung primary pathology, and multifocal bone disease to be negative predictive factors; breast, kidney, or hematological primary pathologies were found to portend improved survival. Scoring on a scale of $0-5$ was based on the number of positive predictors present. The scoring system did not have a defined survival endpoint; however, analysis of the cohort demonstrated a score of $\geq 4$ to have a PPV of $50 \%$ for survival beyond 1 year and a score of $\leq 1$ to have 
a PPV of $100 \%$ for death within 6 months. This scoring system was subsequently updated by Leithner et al. ${ }^{38}$ who removed the pathologic fracture element and compared this modified Bauer score with other predictive scores, including the Tomita, ${ }^{28}$ van der Linden, ${ }^{35}$ Sioutos, ${ }^{33}$ Tokuhashi, ${ }^{29}$ revised Tokuhashi, ${ }^{30}$ and original Bauer scores. ${ }^{37}$ The modified Bauer score was found to be the most clinically useful in terms of its ability to stratify patients into treatment groups (invasive surgery vs minor surgery vs palliative/nonsurgical care) based on significant differences in expected survival. ${ }^{38}$ However, no specific survival endpoint was assayed, limiting the degree to which the system could be used by surgeons with alternative survival thresholds.

Katagiri et al. ${ }^{39}$ similarly used a non-spine-specific cohort comprising 350 patients with one or more bony metastases. They identified significant predictors to be primary tumor pathology and aggressiveness, the presence of visceral or brain metastases, ECOG performance status, history of prior chemotherapy, and the presence of multiple bony metastases. Using these factors, they developed a system with total scores ranging from 0 to 8 , where lower scores portend better survival. Using a threshold of $\leq 2$, their scoring system had sensitivities of $97.9 \%, 89.1 \%$, and $75.3 \%$ for survival at 6 months, 1 year, and 2 years, respectively. Use of the non-spine-specific cohort limited the ability to incorporate neurological status or epidural disease as a predictive factor.

\section{Nomograms, Machine Learning, and Calculators}

More recent scoring systems differ from earlier scoring systems in that they give survival odds at defined postoperative endpoints, are deployed as nomograms or online calculators that eliminate the need for manual calculation by the surgeon, often incorporate laboratory data, and have frequently been developed using machine learning or other artificial intelligence techniques (Table 2). The first of these was the revised system of Katagiri et al., ${ }^{41}$ which incorporated laboratory data to predict survival at 6 months, 1 year, and 2 years in an expanded cohort of 808 patients with symptomatic bone metastases undergoing surgery or radiotherapy. In addition to the previous prognostic factors, the revised scale identified having an abnormality in serum albumin, platelets, calcium, total bilirubin, lactate dehydrogenase, or C-reactive protein as a negative survival predictor. The updated scoring system was found to have superior prognostic ability relative to the original Katagiri system and gave survival probabilities at defined endpoints of 6 months, 1 year, and 2 years.

Shortly thereafter, Ghori et al. ${ }^{42}$ presented the New England Spinal Metastasis Score (NESMS) for predicting survival at 1 year among surgically treated patients. Included within the score are the modified Bauer score of Leithner et al., ${ }^{38}$ the patient's ambulatory status, and serum albumin. It was subsequently tested for its ability to predict 30-day survival using the multicenter National Surgical Quality Improvement Program (NSQIP) database ${ }^{43}$ (area under the curve $[\mathrm{AUC}]=0.71$ ) and externally validated for diagnostic accuracy at 1 year in single-institution cohorts
$($ AUC $=0.732-0.798) .{ }^{44,45}$ The score was able to explain $71 \%-80 \%$ of the variation in the data for 30-day survival, $68 \%$ for the 30 -day major complication rate, and $74 \%$ of the variation for 1-year survival data. ${ }^{42-44}$

The Skeletal Oncology Research Group (SORG) has published a series of predictive algorithms..$^{14,46-48}$ The first was published in 2016 and subsequently deployed as a nomogram and has since been revised and deployed as a series of online calculators for predicting survival at 30 days, 90 days, and 1 year postsurgery. The original score ${ }^{46}$ includes patient age, markers of disease extent, primary pathology, patient ECOG status, and laboratory data (white blood cell count and hemoglobin level). The nomogram uses similar factors; however, the inputs are weighted by the degree to which they were shown to predict survival in the original study ${ }^{46}$ Comparison of the nomogram to the original score has shown the nomogram to have superior predictive power for survival at 30-day, 90-day, and 1-year time points. ${ }^{46,47}$ The nomogram has also been externally validated using a surgical cohort and was shown to have superior prognostic abilities for 1-year postoperative survival relative to the original Tokuhashi, Tomita, modified Bauer, and NESMS scores ${ }^{47}$ Most recently, Karhade and colleagues used a Bayes point machine learning algorithm to develop predictors of 30-day, ${ }^{48} 90$-day, and 1-year survival ${ }^{14}$ which have been deployed as freely available online calculators (30-day: https://sorg-apps.shinyapps.io/ spinemets/; 90-day and 1-year: https://sorg-apps.shinyapps. io/spinemetssurvival/). The 30-day calculator was developed using a cohort of 1790 patients pulled from the NSQIP database ${ }^{48}$ and includes tumor location, functional status, American Society of Anesthesiologists class, and several laboratory values. It was found to explain $78.2 \%$ of the variation in 30-day survival. The calculator for 90day and 1-year outcomes was developed in a biinstitutional cohort of 732 patients using a stochastic gradient boosting algorithm. Like the 30-day calculator, an 80:20 training/ testing split was employed, and the final model was shown to have AUCs of 0.83 at 90 days and 0.89 at 1 year. The diagnostic accuracy was compared with many of the prior scoring systems $\mathrm{s}^{25,28-30,35,38,39,42,46,47}$ and found to be statistically superior to all of these previous scoring systems for both the 90-day and 1-year endpoints. The calculator has since been validated in an external surgical population, ${ }^{49}$ with C-statistics of $0.75-0.81$ and $0.77-0.78$ for 90 -day and 1-year survival, respectively.

Another recently described machine learning modelthe SpineMet scoring system ${ }^{15}$-was developed by Choi and colleagues using a prospective multicenter cohort of 1430 patients who underwent surgical management of spine metastases. Similar to the SORG machine learning calculator, the algorithm incorporates markers of baseline patient function, tumor pathology, systemic disease burden, and prior therapy. Additionally, it was shown to have better predictive power than the Tokuhashi and Tomita scores. It is openly available at www.spinemet.com and has been designed to produce survival predictions at 3,6, 12, and 24 months. Unlike the SORG calculator, it does not include laboratory data, and it has not been externally validated. However, it has the advantages of providing survival expectations at additional time points and having 
TABLE 2. Nomograms and online predictors

\begin{tabular}{|c|c|c|c|c|}
\hline $\begin{array}{l}\text { Scoring } \\
\text { System }\end{array}$ & $\begin{array}{l}\text { Authors } \\
\& \text { Year }\end{array}$ & Population & Predictors & Diagnostic Properties \\
\hline \multicolumn{5}{|l|}{ SORG family } \\
\hline \multirow{9}{*}{ Original } & \multirow{9}{*}{$\begin{array}{l}\text { Paulino } \\
\quad \text { Pereira } \\
\text { et al., } \\
2016^{46}\end{array}$} & $\begin{array}{l}\text { Biinstitutional cohort of } 649 \text { pts } \\
\text { who underwent surgery for } \\
\text { spine metastases }\end{array}$ & Age $\geq 65$ yrs: yes vs no & $\begin{array}{l}\text { AUC: } 0.56-0.70 \text { at } 30 \text { days; } 0.61-0.69 \\
\text { at } 90 \text { days; } 0.65-0.73 \text { at } 1 \mathrm{yr}\end{array}$ \\
\hline & & & ECOG: $0-2$ vs $3-4$ & $\begin{array}{l}\text { Score } \leq 2 \text { : PPV }=99 \% \text { at } 30 \text { days; } 94 \% \\
\quad \text { at } 90 \text { days; } 81 \% \text { at } 1 \mathrm{yr}\end{array}$ \\
\hline & & & Primary pathology & \\
\hline & & & $\begin{array}{l}\text { Presence of multiple spine metastases: yes } \\
\text { vs no }\end{array}$ & \\
\hline & & & $\begin{array}{l}\text { Presence of visceral or brain metastases: } \\
\text { none vs lung/liver vs brain }\end{array}$ & \\
\hline & & & Prior systemic therapy & \\
\hline & & & $W B C \geq 11,000 / \mu \mathrm{L}$ & \\
\hline & & & $\mathrm{Hgb} \leq 10 \mathrm{~g} / \mathrm{dL}$ & \\
\hline & & & $\begin{array}{l}\text { Score } 0-12 \text {; higher score portends poorer } \\
\text { prognosis }\end{array}$ & \\
\hline \multirow{9}{*}{$\begin{array}{l}\text { Nomo- } \\
\text { gram }\end{array}$} & \multirow{9}{*}{$\begin{array}{l}\text { Paulino } \\
\text { Pereira } \\
\text { et al., } \\
2016,{ }^{46} \\
2017^{47}\end{array}$} & $\begin{array}{l}\text { Original: } 46 \text { biinstitutional cohort } \\
\text { of } 649 \text { pts who underwent } \\
\text { surgery for spine metastases }\end{array}$ & $\mathrm{Hgb}$ & $\begin{array}{l}\text { AUC: } 0.65-0.76 \text { at } 30 \text { days; } 0.70-0.74 \\
\quad \text { at } 90 \text { days; } 0.77-0.78 \text { at } 1 \mathrm{yr}\end{array}$ \\
\hline & & $\begin{array}{l}\text { External validation }{ }^{47} \text { in cohort of } \\
100 \text { surgically treated pts w/ } \\
\text { spine metastases }\end{array}$ & WBC & \\
\hline & & & Age & \\
\hline & & & Prior systemic therapy: yes vs no & \\
\hline & & & $\begin{array}{l}\text { Visceral/brain metastases: none vs lung/liver } \\
\text { vs brain }\end{array}$ & \\
\hline & & & Mobile spine metastases: 1 vs $\geq 1$ & \\
\hline & & & Primary tumor type & \\
\hline & & & ECOG: $0-2$ vs 3 or 4 & \\
\hline & & & $\begin{array}{l}\text { Score: } 0-550 ; \text { higher score predicts better } \\
\quad \text { survival }\end{array}$ & \\
\hline \multirow{8}{*}{$\begin{array}{l}\text { 30-day } \\
\text { machine } \\
\text { learning } \\
\text { calculator }\end{array}$} & \multirow{8}{*}{$\begin{array}{l}\text { Karhade } \\
\text { et al., } \\
2019^{48}\end{array}$} & $\begin{array}{l}\text { Multicenter cohort of } 1760 \mathrm{pts} \\
\text { from NSQIP database }\end{array}$ & WBC & $\begin{array}{l}\text { AUC: } 0.769 \text { in training cohort \& } 0.782 \\
\text { in test cohort for } 30 \text {-day mortality }\end{array}$ \\
\hline & & $\begin{array}{l}\text { Training using } 80 \% \text { of cohort \& } \\
\text { testing w/ } 20 \% \text { of cohort }\end{array}$ & Albumin & \\
\hline & & & Hematocrit & \\
\hline & & & Alkaline phosphatase & \\
\hline & & & ASA class: II vs III, vs IV or V & \\
\hline & & & Location: cervical vs thoracic vs lumbosacral & \\
\hline & & & Functional status: independent vs dependent & \\
\hline & & & Possible predicted mortality: $0.8-94.3 \%$ & \\
\hline
\end{tabular}

been developed from a multinational, prospective cohort. Table 3 summarizes the factors incorporated in the scoring systems and calculators described above.

\section{How Accurate Are Predictors of Survival?}

Given the abundance of scoring systems that have been created, the question has been raised as to which has the greatest prognostic accuracy. To answer this question, comparison studies have been performed (Table 4). Using a single institutional retrospective external validation, Ahmed et $a .^{40}$ found that the SORG nomogram had the best overall predictive value but noted that the prognostic accuracy of the different scoring systems varied based on primary pathology. For example, they noted that the van der Linden system had the highest accuracy for predicting 
» CONTINUED FROM PAGE 141

TABLE 2. Nomograms and online predictors

\begin{tabular}{|c|c|c|c|c|}
\hline $\begin{array}{l}\text { Scoring } \\
\text { System }\end{array}$ & $\begin{array}{l}\text { Authors } \\
\& \text { Year }\end{array}$ & Population & Predictors & Diagnostic Properties \\
\hline $\begin{array}{l}\text { SORG family } \\
\text { (continued) }\end{array}$ & & & & \\
\hline \multirow{17}{*}{$\begin{array}{l}90 \text {-day } \\
\& 1-y r \\
\text { machine } \\
\text { learning } \\
\text { calculator }\end{array}$} & \multirow{17}{*}{$\begin{array}{l}\text { Karhade } \\
\text { et al., } \\
2019^{14}\end{array}$} & $\begin{array}{l}\text { Biinstitutional cohort of } 732 \text { pts } \\
\text { who underwent surgical man- } \\
\text { agement of spine metastases }\end{array}$ & Primary tumor histology & $\begin{array}{l}\text { AUC: } 0.83 \text { at } 90 \text { days for training \& } \\
\text { testing subsets; } 0.85 \text { at } 1 \mathrm{yr} \text { in train- } \\
\text { ing set } \& 0.89 \text { at } 1 \text { yr in testing set }\end{array}$ \\
\hline & & $\begin{array}{l}\text { Training using } 80 \% \text { of cohort \& } \\
\text { testing w/ } 20 \% \text { of cohort }\end{array}$ & ECOG: $0-2$ vs 3 or 4 & \\
\hline & & & ASIA: A-D vs E & \\
\hline & & & CCl: yes vs no & \\
\hline & & & Visceral metastases: yes vs no & \\
\hline & & & Brain metastases: yes vs no & \\
\hline & & & Prior systemic therapy & \\
\hline & & & No. of spine metastases: 1 or 2 vs $\geq 3$ & \\
\hline & & & BMI & \\
\hline & & & $\mathrm{Hgb}$ & \\
\hline & & & Platelet count & \\
\hline & & & Absolute lymphocyte count & \\
\hline & & & Absolute neutrophil count & \\
\hline & & & Creatinine & \\
\hline & & & INR & \\
\hline & & & Albumin & \\
\hline & & & Alkaline phosphatase & \\
\hline \multirow{8}{*}{$\begin{array}{l}\text { Revised } \\
\text { Katagiri }\end{array}$} & \multirow{8}{*}{$\begin{array}{l}\text { Katagiri } \\
\text { et al., } \\
2014^{41}\end{array}$} & $\begin{array}{l}808 \text { pts w/ symptomatic bone } \\
\text { metastases treated w/ surgery } \\
(n=59) \text { or radiotherapy; surgi- } \\
\text { cal pts had expected survival } \\
\geq 2 \text { mos for extremity lesions \& } \\
\geq 6 \text { mos for spinal metastases } \\
(n=12)\end{array}$ & ECOG performance status & Score $\leq 3$ : \\
\hline & & & $\begin{array}{l}\text { Lab values: normal, abnormal (CRP } \geq 0.4 \mathrm{mg} / \\
\mathrm{dL}, \mathrm{LDH} \geq 250 \mathrm{IU} / \mathrm{L}, \text { albumin }<3.7 \mathrm{~g} / \mathrm{dL} \text { ), or } \\
\text { critical (platelets }<100,000 / \mu \mathrm{L}, \mathrm{Ca}^{2+} \geq 10.3 \\
\mathrm{mg} / \mathrm{dL} \text {, or total bilirubin } \geq 1.4 \mathrm{mg} / \mathrm{dL} \text { ) }\end{array}$ & $\begin{array}{l}\text { At } 6 \text { mos: } S n=22.5 \% ; S p=99.4 \% \\
\quad P P V=98.1 \% ; N P V=49.5 \%\end{array}$ \\
\hline & & & $\begin{array}{l}\text { Primary tumor type: slow, moderate, or rapid } \\
\text { growth }\end{array}$ & $\begin{array}{l}\text { At } 1 \text { yr: } S n=33.1 \% ; S p=98.3 \% ; P P V \\
\quad=91.4 \% ; N P V=72.4 \%\end{array}$ \\
\hline & & & Presence of visceral or brain metastases & $\begin{array}{l}\text { At } 2 \text { yrs: } S n=44.1 \% ; S p=96.3 \% ; P P V \\
\quad=78.1 \% ; N P V=85.2 \%\end{array}$ \\
\hline & & & Prior chemotherapy & Score $\geq 7$ : \\
\hline & & & Presence of multiple skeletal fractures & $\begin{array}{l}<6 \text { mos: } S n=73.1 \% ; \text { Sp }=79.3 \% ; \text { PPV } \\
\quad=72.9 \% ; \text { NPV }=79.4 \%\end{array}$ \\
\hline & & & $\begin{array}{l}\text { Score: } 0-10 \text {; higher score portends poorer } \\
\text { survival }\end{array}$ & $\begin{array}{l}<1 \mathrm{yr}: \mathrm{Sn}=63.7 \% ; \mathrm{Sp}=92.8 \% ; \mathrm{PPV}= \\
\quad 94.0 \% ; \mathrm{NPV}=58.9 \%\end{array}$ \\
\hline & & & & $\begin{array}{l}<2 \text { yrs: } S n=55.3 \% ; S p=96.2 \% ; \text { PPV } \\
\quad=98.0 \% ; N P V=39.2 \%\end{array}$ \\
\hline
\end{tabular}

survival in patients with breast primary pathology, whereas several scores had statistically similar predictive power for hematological primary pathology. In contrast, Westermann et al..$^{50}$ found that the revised score by Morgen and colleage $^{32}$ had the greatest prognostic ability. The SORG scoring systems were not evaluated by the Westermann group, and the Morgen revision was not considered by Ahmed et al., preventing direct comparison of the results. 
» CONTINUED FROM PAGE 142

TABLE 2. Nomograms and online predictors

\begin{tabular}{|c|c|c|c|c|}
\hline $\begin{array}{l}\text { Scoring } \\
\text { System }\end{array}$ & $\begin{array}{l}\text { Authors } \\
\& \text { Year }\end{array}$ & Population & Predictors & Diagnostic Properties \\
\hline \multirow{7}{*}{ NESMS } & \multirow{7}{*}{$\begin{array}{l}\text { Ghori et } \\
\text { al., } \\
2015^{42}\end{array}$} & $\begin{array}{l}\text { Original population was single- } \\
\text { institution cohort of } 307 \text { surgi- } \\
\text { cally treated pts w/ } \geq 1 \text { spine } \\
\text { metastases }^{42}\end{array}$ & Modified Bauer score: ${ }^{38} \leq 2$ vs $\geq 3$ & AUC: 30 days $=0.71 ; 1 \mathrm{yr}=0.74-0.80$ \\
\hline & & $\begin{array}{l}\text { Subsequent assessment for } \\
\text { 30-day survival in multicenter } \\
\text { cohort of } 776 \text { pts from NSQIP }\end{array}$ & Albumin: $\leq 3.4 \mathrm{~g} / \mathrm{dL}$ vs $\geq 3.5 \mathrm{~g} / \mathrm{dL}$ & Score $\geq 2$ : \\
\hline & & $\begin{array}{l}\text { External validation in single- } \\
\text { institution cohorts of } 290 \text { pts } \\
\text { undergoing radiotherapy }{ }^{44} \& \\
161 \text { pts undergoing surgery }\end{array}$ & Ambulatory status: intact vs impaired & $\begin{array}{l}\text { At } 1 \text { yr: } S n=69.7-83.1 \% ; S p= \\
41.0-66.7 \% ; P P V=34.4-64.2 \% ; \\
\text { NPV }=69.6-88.5 \%\end{array}$ \\
\hline & & & $\begin{array}{l}\text { Score: } 0-3 \text {; higher score portends better } \\
\text { survival }\end{array}$ & $\begin{array}{l}\text { 30-day survival: } \mathrm{Sn}=63.0 \% ; \mathrm{Sp}= \\
\quad 67.8 \% ; \mathrm{PPV}=93.9 \% ; \mathrm{NPV}=18.8 \%\end{array}$ \\
\hline & & & & $\begin{array}{l}\text { 30-day complication }(\text { score }<2): S n= \\
66.9 \% ; \mathrm{Sp}=47.6 \% ; \mathrm{PPV}=55.2 \% \\
\text { NPV }=59.9 \%\end{array}$ \\
\hline & & & & $\begin{array}{l}\text { 30-day reop: } S n=60.4 \% ; S p=50 \% \\
\text { PPV }=93.3 \% ; N P V=9.9 \%\end{array}$ \\
\hline & & & & $\begin{array}{l}\text { 30-day readm: } S n=58.7 \% ; S p= \\
34.7 \% ; \text { PPV }=86.6 \% ; \text { NPV }=10.5 \%\end{array}$ \\
\hline \multirow{12}{*}{ SpineMet } & \multirow{12}{*}{$\begin{array}{l}\text { Choi et al., } \\
2019^{15}\end{array}$} & $\begin{array}{l}\text { Multicenter prospective cohort of } \\
1430 \text { pts w/ spinal metastases } \\
\text { who underwent surgery }\end{array}$ & $\begin{array}{l}\text { Primary tumor type: lung vs breast vs renal } \\
\text { vs prostate vs myeloma vs gastric vs } \\
\text { sarcoma vs other vs unknown }\end{array}$ & $\begin{array}{l}\text { AUC: } 0.71-0.76 \text { at } 3 \text { mos; } 0.68-0.73 \\
\text { at } 2 \text { yrs }\end{array}$ \\
\hline & & Split 88:12 btwn training \& testing & $\begin{array}{l}\text { Mobility: no crutches vs } 1 \text { crutch vs } 2 \\
\text { crutches vs wheelchair vs bedbound }\end{array}$ & \\
\hline & & & $\begin{array}{l}\text { Regular analgesic: none vs nonopioid vs } \\
\text { weak opioid vs strong opioid }\end{array}$ & \\
\hline & & & $\begin{array}{l}\text { Extraspinal bone metastases: } 0 \text { vs } 1 \text { or } 2 \text { vs } \\
\quad \geq 3\end{array}$ & \\
\hline & & & Visceral metastases: none vs 1 vs $\geq 2$ & \\
\hline & & & Liver metastases: yes vs no & \\
\hline & & & Lung metastases: yes vs no & \\
\hline & & & ASA: I vs I| vs III vs IV or V & \\
\hline & & & Prior chemotherapy: yes vs no & \\
\hline & & & Prior spine radiotherapy: yes vs no & \\
\hline & & & Tumor at cervical or thoracic level: yes vs no & \\
\hline & & & $\begin{array}{l}\text { Possible predicted mortality: } 3 \text { mos }= \\
2.32-80.5 \% ; 6 \text { mos }=4.62-96.26 \% ; 12 \\
\text { mos }=8-99.7 \% ; 24 \text { mos }=12.81-99.99 \%\end{array}$ & \\
\hline
\end{tabular}

$\mathrm{ASA}=$ American Society of Anesthesiologists; $\mathrm{ASI}$ = American Spinal Injury Association; $\mathrm{CCl}=$ Charlson Comorbidity Index; $\mathrm{CRP}=\mathrm{C}$-reactive protein; $\mathrm{Hgb}=$ hemoglobin; INR = international normalized ratio; LDH = lactate dehydrogenase; readm = readmission; WBC = white blood cell count.

Westermann et al. similarly did not perform subanalyses based on tumor pathology.

Karhade et al. found their machine learning-based 90day and 1-year calculators to have a higher AUC than any of the following scoring systems: original Tokuhashi, revised Tokuhashi, modified Bauer, Tomita, original Katagiri, van der Linden, NESMS, Bollen, ${ }^{60}$ SORG classic, and SORG nomogram scores..$^{14}$ Choi et al. ${ }^{15}$ similarly found the SpineMet scoring system to be superior to the Tomita and Tokuhashi scores, and Paulino Pereira et al. ${ }^{47}$ showed the SORG nomogram to have superior predictive power relative to the original Tokuhashi, Tomita, modified Bauer, and NESMS scores.

\section{Relevance of Survival Predictors to Modern Practice}

Expected patient survival has long been one of the 


\begin{tabular}{|c|c|c|c|c|c|c|c|c|c|c|c|c|c|c|c|c|c|c|c|c|c|c|c|c|c|c|c|c|c|c|c|c|c|c|c|}
\hline & ह & $\frac{\tilde{U}}{\frac{0}{2}}$ & & 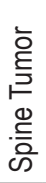 & & & 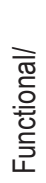 & 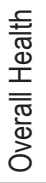 & & & $\begin{array}{l}\mathbb{D} \\
\mathbb{N} \\
\mathbb{N} \\
. \mathscr{D}\end{array}$ & $\begin{array}{l}\frac{}{\Phi} \\
\text { 일 } \\
\text { ๓ }\end{array}$ & & & 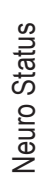 & & & $\begin{array}{l}\stackrel{x}{ } \\
\stackrel{ }{\circ} \text { 은 } \\
\text { ․ }\end{array}$ & & 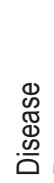 & $\begin{array}{l}\mathscr{N} \\
\mathbb{d} \\
\text { 이 } \\
\text { 오 }\end{array}$ & & & & & & & 음 & $\begin{array}{l}\stackrel{\mathscr{d}}{D} \\
\stackrel{\mathbb{N}}{>}\end{array}$ & & & & & & \\
\hline $\begin{array}{l}\text { Scoring } \\
\text { System* }\end{array}$ & 通 & $\sum_{\infty}$ & 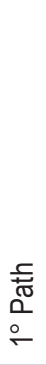 & $\underset{\Xi}{\Phi}$ & 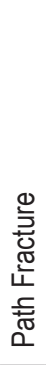 & $\begin{array}{l}\mathscr{n} \\
\underline{n}\end{array}$ & $\begin{array}{l}\text { రூ } \\
\text { ய }\end{array}$ & ৫ & $\bar{U}$ & 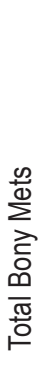 & 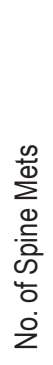 & 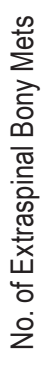 & 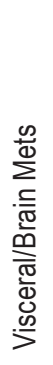 & $\begin{array}{l}\bar{\Phi} \\
\frac{\mathscr{c}}{\mathrm{C}} \\
\text { 니 }\end{array}$ & $\frac{\pi}{\infty}$ & 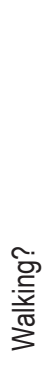 & 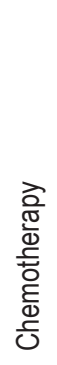 & 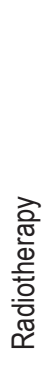 & 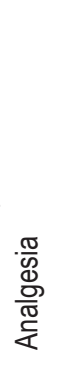 & 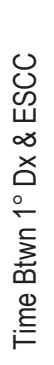 & 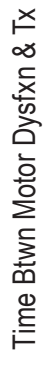 & 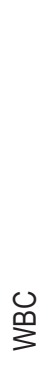 & $\stackrel{u}{z}$ & $\frac{0}{4}$ & 음 & 포 & \pm & $\stackrel{\Upsilon}{\underline{Z}}$ & 은 & $\frac{n}{\frac{1}{4}}$ & $\stackrel{\overline{\bar{m}}}{\stackrel{一}{\vdash}}$ & $\frac{n}{\frac{n}{0}}$ & $\begin{array}{l}\text { ㅁ } \\
\text { ㄱ }\end{array}$ & $\stackrel{+}{\widetilde{J}}$ & ปัँ \\
\hline Tokuhashi & - & - & + & - & - & + & - & - & - & - & + & + & + & + & - & - & - & - & - & - & - & - & - & - & - & - & - & - & - & - & - & - & - & - & - \\
\hline $\begin{array}{l}\text { Revi- } \\
\text { sion}^{2}\end{array}$ & - & - & + & - & - & + & - & - & - & - & + & + & + & + & - & - & - & - & - & - & - & - & - & - & - & - & - & - & - & - & - & - & - & - & - \\
\hline Morgen $^{3}$ & - & - & + & - & - & + & - & - & - & - & + & - & + & + & - & - & - & - & - & - & - & - & - & - & - & - & - & - & - & - & - & - & - & - & - \\
\hline Sioutos $^{4}$ & - & - & + & - & - & - & - & - & - & - & - & + & - & - & - & + & - & - & - & - & - & - & - & - & - & - & - & - & - & - & - & - & - & - & - \\
\hline Bauer $^{5}$ & - & - & + & - & + & - & - & - & - & + & - & - & + & - & - & - & - & - & - & - & - & - & - & - & - & - & - & - & - & - & - & - & - & - & - \\
\hline $\begin{array}{l}\text { Modifi- } \\
\text { cation }^{6}\end{array}$ & - & - & + & - & - & - & - & - & - & + & - & - & + & - & - & - & - & - & - & - & - & - & - & - & - & - & - & - & - & - & - & - & - & - & - \\
\hline Tomita $^{7}$ & - & - & + & - & - & - & - & - & - & + & - & - & + & - & - & - & - & - & - & - & - & - & - & - & - & - & - & - & - & - & - & - & - & - & - \\
\hline Katagiri $^{8}$ & - & - & + & - & - & - & + & - & - & + & - & - & + & - & - & - & + & - & - & - & - & - & - & - & - & - & - & - & - & - & - & - & - & - & - \\
\hline $\begin{array}{l}\text { Van der } \\
\text { Linden }^{9}\end{array}$ & - & - & + & - & - & + & - & - & - & - & - & - & + & - & - & - & - & - & - & - & - & - & - & - & - & - & - & - & - & - & - & - & - & - & - \\
\hline Rades $^{10}$ & - & - & + & - & - & - & - & - & - & + & - & - & + & - & - & + & - & - & - & + & + & - & - & - & - & - & - & - & - & - & - & - & - & - & - \\
\hline OSRI11 & - & - & + & - & - & + & - & - & - & - & - & - & - & - & - & - & - & - & - & - & - & - & - & - & - & - & - & - & - & - & - & - & - & - & - \\
\hline \multicolumn{36}{|l|}{ SORG } \\
\hline $\begin{array}{l}\text { Origi- } \\
\text { nal }^{12}\end{array}$ & + & - & + & - & - & - & + & - & - & - & + & - & + & - & - & - & + & - & - & - & - & + & - & - & + & - & - & - & - & - & - & - & - & - & - \\
\hline $\begin{array}{l}\text { Nomo- } \\
\text { gram }^{12,13}\end{array}$ & + & - & + & - & - & - & + & - & - & - & + & - & + & - & - & - & + & - & - & - & - & + & - & - & + & - & - & - & - & - & - & - & - & - & - \\
\hline $\begin{array}{l}\text { 30-day } \\
\text { calc }^{14}\end{array}$ & - & - & - & + & - & - & + & + & - & - & - & - & - & - & - & + & - & - & - & - & - & + & - & - & - & + & - & - & + & + & - & - & - & - & - \\
\hline $\begin{array}{l}\text { 90-day } \\
\& 1-y r \\
\text { calc }^{15}\end{array}$ & - & + & + & - & - & - & + & + & + & - & + & - & + & - & - & - & + & - & - & - & - & - & + & + & + & - & + & + & + & + & - & - & - & - & + \\
\hline $\begin{array}{c}\text { Revised } \\
\text { Kata- } \\
\text { giri16 }\end{array}$ & - & - & + & - & - & - & + & - & - & - & + & - & + & - & - & - & + & - & - & - & - & - & - & - & - & - & + & - & + & - & + & + & + & + & - \\
\hline NESMS $^{17}$ & - & - & + & - & - & - & - & - & - & + & - & - & + & - & - & + & - & - & - & - & - & - & - & - & - & - & - & - & + & - & - & - & - & - & - \\
\hline SpineMet ${ }^{18}$ & - & - & + & + & - & - & - & + & - & - & - & + & + & - & - & + & + & + & + & - & - & - & - & - & - & - & - & - & - & - & - & - & - & - & - \\
\hline
\end{tabular}

$\mathrm{Alb}=$ albumin level; $\mathrm{ALC}=$ absolute lymphocyte count; $\mathrm{ALP}=$ alkaline phosphatase; $\mathrm{ANC}=$ absolute neutrophil count; calc = machine learning calculator; $\mathrm{Ca}^{2+}=$ total serum calcium level; $\mathrm{Crt}=$ creatinine; $\mathrm{Dx}=$ diagnosis; dysfxn = dysfunction; $\mathrm{Hct}=$ hematocrit; mets = metastases; neuro = neurological; path = pathologic; Plt = platelet count; TBili = total bilirubin; $1^{\circ}=$ primary; $2^{\circ}=$ secondary; + = present; $-=$ absent.

* The references are as follows: $1=$ Tokuhashi et al., $1990^{29} ; 2=$ Tokuhashi et al., 2005"30; 3 = Morgen et al., 201832; 4 = Sioutos et al., $1995^{33} ; 5=$ Bauer \& Wedin, $1995^{37}$; $6=$ Leithner et al., 200838; $7=$ Tomita et al., 200128; 8 = Katagiri et al., 200539; $9=$ Van der Linden et al., 200535; $10=$ Rades et al., $2008^{34 ;} 11=$ Balain et al., $2013^{36} ; 12$ = Paulino Pereira et al., 201646; 13 = Paulino Pereira et al., 201747; $14=$ Karhade et al., 201948; 15 = Karhade et al., 201914; $16=$ Katagiri et al., $2014^{41} ; 17=$ Ghori et al., $2015^{42} ; 18=$ Choi et al., $2019^{15}$. 
TABLE 4. Reviews comparing prognostic accuracy of survival predictors in patients with spinal metastases

\begin{tabular}{|c|c|c|c|}
\hline $\begin{array}{l}\text { Authors } \\
\text { \& Year }\end{array}$ & $\begin{array}{l}\text { Scoring Systems } \\
\text { Compared }\end{array}$ & Population & Findings \\
\hline \multirow{14}{*}{$\begin{array}{l}\text { Ahmed } \\
\text { et al., } \\
2018^{40}\end{array}$} & Bauer original & $\begin{array}{l}\text { Retrospective, single- } \\
\text { institution cohort of } 176 \\
\text { surgically treated pts w/ } \\
\text { spinal metastases }\end{array}$ & AUC for 30-day, 90-day, \& 1-yr survival \\
\hline & Bauer modified & & Bauer original: 0.63 at 30 days; 0.63 at 90 days; 0.69 at $1 \mathrm{yr}$ \\
\hline & Katagiri original & & Bauer modified: 0.59 at 30 days; 0.62 at 90 days; 0.71 at $1 \mathrm{yr}$ \\
\hline & SORG classic & & Katagiri original: 0.73 at 30 days; 0.70 at 90 days; 0.78 at $1 \mathrm{yr}$ \\
\hline & SORG nomogram & & SORG classic: 0.77 at 30 days; 0.67 at 90 days; 0.77 at $1 \mathrm{yr}$ \\
\hline & Tokuhashi original & & SORG nomogram: 0.81 at 30 days; 0.70 at 90 days; 0.78 at $1 \mathrm{yr}$ \\
\hline & Tokuhashi revised & & Tokuhashi original: 0.74 at 30 days; 0.69 at 90 days; 0.78 at $1 \mathrm{yr}$ \\
\hline & Tomita & & Tokuhashi revised: 0.71 at 30 days; 0.67 at 90 days; 0.77 at $1 \mathrm{yr}$ \\
\hline & Van der Linden & & Tomita: 0.59 at 30 days; 0.60 at 90 days; 0.70 at $1 \mathrm{yr}$ \\
\hline & & & Van der Linden: 0.74 at 30 days; 0.66 at 90 days; 0.71 at $1 \mathrm{yr}$ \\
\hline & & & SORG nomogram is overall best predictor of 30-day survival; Tomita is worst \\
\hline & & & SORG nomogram \& Katagiri are tied for best predictor of 90 -day survival; Tomita is worst \\
\hline & & & $\begin{array}{l}\text { SORG nomogram, original Tokuhashi, revised Tokuhashi \& Katagiri provide comparable } \\
\text { prognostic ability for 1-yr survival; original Bauer score is worst }\end{array}$ \\
\hline & & & $\begin{array}{l}\text { Best predictor for both } 30 \text { - \& } 90 \text {-day endpoint is highly dependent on primary tumor } \\
\text { pathology; multiple predictors have similar performance for } 1 \text {-yr survival }\end{array}$ \\
\hline \multirow{10}{*}{$\begin{array}{l}\text { Hibberd \& } \\
\text { Quan, } \\
2017^{57}\end{array}$} & Bauer original & $\begin{array}{l}\text { Retrospective, single-insti- } \\
\text { tution cohort of } 61 \text { pts } \\
\text { who underwent surgical } \\
\text { Tx of spine metastases }\end{array}$ & $\begin{array}{l}\text { Predictive accuracy (reported as percentage of pts where prognostic score predicted } \\
\text { survival; } \kappa=\text { degree of agreement btwn predicted \& observed survival) }\end{array}$ \\
\hline & Bauer modified & & Bauer original: $62 \% ; \kappa=0.41$ \\
\hline & Sioutos & & Bauer modified: $69 \% ; \kappa=0.50$ \\
\hline & Tokuhashi original & & Sioutos: $61 \% ; \kappa=0.26$ \\
\hline & Tokuhashi revised & & Tokuhashi original: $59 \% ; \kappa=0.39$ \\
\hline & Tomita & & Tokuhashi revised: $72 \% ; \kappa=0.41$ \\
\hline & Van der Linden & & Tomita: $51 \% ; \kappa=0.43$ \\
\hline & & & Van der Linden: $59 \% ; \kappa=0.17$ \\
\hline & & & $\begin{array}{l}\text { Revised Tokuhashi \& modified Bauer scores have greater predictive accuracy; Tomita } \\
\text { system has worst predictive accuracy }\end{array}$ \\
\hline & & & $\begin{array}{l}\text { Degree of agreement btwn predicted \& observed survival was greatest for modified } \\
\text { Bauer score \& worst for van der Linden score }\end{array}$ \\
\hline \multirow{7}{*}{$\begin{array}{l}\text { Leithner } \\
\text { et al., } \\
2008^{38}\end{array}$} & Bauer original & $\begin{array}{l}\text { Retrospective, single-insti- } \\
\text { tution cohort of } 69 \text { pts } \\
\text { who underwent surgical } \\
\text { Tx of spine metastases }\end{array}$ & $\begin{array}{l}\text { Using log-rank tests, all scoring systems found to have prognostic value in analysis } \\
\text { including all tumor types; all scoring systems except original Tokuhashi scoring system } \\
\text { found to have prognostic value in analysis excluding myeloma pts }(n=59)\end{array}$ \\
\hline & Bauer modified & & No statistical comparison btwn groups for superiority \\
\hline & Sioutos & & \\
\hline & Tokuhashi original & & \\
\hline & Tokuhashi revised & & \\
\hline & Tomita & & \\
\hline & Van der Linden & & \\
\hline
\end{tabular}


» CONTINUED FROM PAGE 145

TABLE 4. Reviews comparing prognostic accuracy of survival predictors in patients with spinal metastases

\begin{tabular}{|c|c|c|c|}
\hline $\begin{array}{l}\text { Authors } \\
\& \text { Year }\end{array}$ & $\begin{array}{l}\text { Scoring Systems } \\
\text { Compared }\end{array}$ & Population & Findings \\
\hline \multirow{3}{*}{$\begin{array}{l}\text { Majeed } \\
\text { et al., } \\
2012^{58}\end{array}$} & Tokuhashi revised & $\begin{array}{l}\text { Retrospective, single-insti- } \\
\text { tution cohort of } 55 \text { pts } \\
\text { who underwent surgical } \\
\text { Tx of spine metastases }\end{array}$ & $\begin{array}{l}\text { Retroactive analysis of revised Tokuhashi sorting shows significant difference btwn } \\
\text { expected \& observed survival distribution }\left(\chi^{2}=33.21, \mathrm{df}=2 ; \mathrm{p}<0.0001\right)\end{array}$ \\
\hline & Tomita & & Tomita score not correlated w/ survival \\
\hline & & & $\begin{array}{l}\text { Revised Tokuhashi \& Tomita scores are both poor survival predictors on their own, but } \\
\text { may be useful if used in conjunction w/ other factors }\end{array}$ \\
\hline \multirow{11}{*}{$\begin{array}{l}\text { Wester- } \\
\text { mann } \\
\text { et al., } \\
2020^{50}\end{array}$} & Bauer-modified & $\begin{array}{l}\text { Retrospective, single- } \\
\text { institution cohort of } \\
223 \text { pts who underwent } \\
\text { surgery for extradural } \\
\text { metastases }\end{array}$ & AUC for 1-, 3-, \& 12-mo survival (pointwise analysis) \\
\hline & OSRI & & Bauer modified: 0.69 at $1 \mathrm{mo} ; 0.65$ at $3 \mathrm{mos} ; 0.69$ at $1 \mathrm{yr}$ \\
\hline & Tokuhashi original & & OSRI: 0.60 at $1 \mathrm{mo} ; 0.64$ at $3 \mathrm{mos} ; 0.67$ at $1 \mathrm{yr}$ \\
\hline & Tokuhashi revised & & Tokuhashi original: 0.63 at $1 \mathrm{mo} ; 0.68$ at $3 \mathrm{mos} ; 0.71$ at $1 \mathrm{yr}$ \\
\hline & $\begin{array}{l}\text { Tokuhashi: Morgen } \\
\text { modification }\end{array}$ & & Tokuhashi revised: 0.60 at $1 \mathrm{mo} ; 0.64$ at 3 mos; 0.71 at $1 \mathrm{yr}$ \\
\hline & Tomita & & Tokuhashi: Morgen modification: 0.65 at $1 \mathrm{mo} ; 0.68$ at 3 mos; 0.71 at $1 \mathrm{yr}$ \\
\hline & Van der Linden & & Tomita: 0.61 at $1 \mathrm{mo} ; 0.65$ at $3 \mathrm{mos} ; 0.77$ at $1 \mathrm{yr}$ \\
\hline & & & Van der Linden: 0.53 at $1 \mathrm{mo} ; 0.51$ at $3 \mathrm{mos} ; 0.59$ at $1 \mathrm{yr}$ \\
\hline & & & $\begin{array}{l}\text { Only the original Tokuhashi, revised Tokuhashi, Morgen revision to the Tokuhashi score, } \\
\text { Tomita score, \& modified Bauer score successfully categorized pts into groups w/ } \\
\text { significantly different median survivals }\end{array}$ \\
\hline & & & $\begin{array}{l}\text { Only the original Tokuhashi (53.4\%), revised Tokuhashi }(65.5 \%) \text {, Morgen revision to the } \\
\text { Tokuhashi }(73.1 \%) \text {, \& modified Bauer score }(54.3 \%) \text { successfully classified pt survival } \\
\text { in }>50 \% \text { of cases; random chance }=33 \%\end{array}$ \\
\hline & & & Morgen revision of Tokuhashi score was found to have the greatest prognostic value \\
\hline \multirow{7}{*}{$\begin{array}{l}\text { Wibmer } \\
\text { et al., } \\
2011^{59}\end{array}$} & Bauer original & $\begin{array}{l}\text { Retrospective, single-insti- } \\
\text { tution cohort of } 254 \text { pts } \\
\text { who underwent surgical } \\
(n=62) \text { or conservative } \\
(n=192) \text { management } \\
\text { of spine metastases }\end{array}$ & $\begin{array}{l}\text { Only Bauer \& modified Bauer adequately parsed pts into } 3 \text { significantly different groups; } \\
\text { all others had prognostic value only when comparing group w/ best predicted survival } \\
\text { to group w/ worst predicted survival; significant comparisons were: }\end{array}$ \\
\hline & Bauer modified & & Tokuhashi original: $0-5$ (worst), $<9-12$ (best) \\
\hline & Sioutos & & Tokuhashi revised: 0-8 (worst), $<12-15$ (best) \\
\hline & Tokuhashi original & & Tomita: 2-3 (best), >6-7 (poor), \& 8-10 (worst) \\
\hline & Tokuhashi revised & & Sioutos: 0 (best), >2 (worst in cohort) \\
\hline & Tomita & & Van der Linden: 0-3 (worst), <6 (best) \\
\hline & Van der Linden & & $\begin{array}{l}\text { Original \& modified Bauer scores are most reliable for predicting survival in mixed surgi- } \\
\text { cal/nonsurgical cohort }\end{array}$ \\
\hline
\end{tabular}

most strongly weighted metrics for determining surgical candidacy in patients with spinal metastases. However, the classic teaching that patients should have a 3- to 6-month minimum survival to be considered for surgery is being challenged. Recently, Dea et al..$^{51}$ and the AO Spine Knowledge Forum Tumor group retrospectively analyzed quality-of-life (QOL) outcomes in a prospectively followed multicenter cohort of surgically treated patients with spinal metastasis. They found that patients experienced statistically significant QOL improvements in as little as 6 weeks following surgery, suggesting that the 3-month cutoff for surgical candidacy may miss an 
important segment of patients who would benefit from surgical intervention.

Additionally, the 3-month guideline dates to the late $1990 \mathrm{~s},{ }^{52}$ when essentially all surgeries involved an open approach. Since that time, there have been significant advances in minimally invasive surgery, including the description of mini-open approaches and the widespread dissemination of percutaneous instrumentation procedures. These techniques have been found to significantly reduce the morbidity of surgery for spinal metastases and speed patient recovery. ${ }^{11}$ Consequently, where the open surgeries of the past may have left patients debilitated for up to 3 months, minimally invasive surgery techniques allow patients to return to ambulating as soon as 4 days postoperatively ${ }^{53}$ and return to normal activities within 4 weeks.

In comparing the newer survival predictors (e.g., the SORG calculators) to older predictors (e.g., the Tomita and Tokuhashi systems), we note that there has been a push toward calculators that provide a more comprehensive assessment of patients. These calculators, which were developed at comprehensive cancer centers employing the most advanced therapeutic options (e.g., stereotactic radiosurgery and immunotherapy), are likely bringing the field closer to the point of being able to accurately predict patient survival. Yet most survival predictors have failed to incorporate new therapeutic advances ${ }^{54}$ or discoveries in the study of body morphometrics (e.g., sarcopenia and cachexia). ${ }^{24,27}$ This has led some ${ }^{55}$ to question whether current survival predictors miss the mark by restricting their focus to laboratory data and conventional tumor descriptors, such as the primary pathology and number of metastases. We believe that a comprehensive clinical calculator will need to incorporate the morphometric parameters along with immunohistological tumor markers, specifically mutations in genes for which targeted chemotherapies have been developed (e.g., vascular endothelial growth factor). Such data-driven calculators will take advantage of the larger stores of information now available because of electronic medical records. This includes data on focused radiotherapy, which has heretofore been ignored in survival calculators, but which in the near future may become the standard of care for ESCC without concurrent instability. ${ }^{56}$ Yet in striving for these new predictors, it is imperative to keep in mind that they are not perfect decision tools and may miss a subset of patients who could still experience symptomatic benefit.

Additionally, to have maximal clinical utility, the predictor should have a rapid learning curve, be deployable as an application that eliminates the need for manual calculation, and be solvable for a given survival endpoint. With regard to survival endpoint, thresholds of 3-6 months have been used to define surgical candidacy. However, more recent data suggest that patients might experience significant improvement in QOL as soon as 6 weeks postsurgery. ${ }^{51}$ Therefore, a clinically useful predictor should be capable of giving survival odds at whatever threshold is used by the treating physician to determine surgical candidacy.

\section{Conclusions}

The drive for an accurate and efficient predictor of life expectancy among patients with spine metastases has been a goal since the late 1990s when surgery became the gold standard of therapy for spinal metastases. Many scoring systems have been advanced, but until the advent of newer machine learning-based calculators, the majority have been overly simplistic and only of limited prognostic value. Expansion of machine learning techniques will likely improve diagnostic accuracy and facilitate clinical implementation. They may additionally allow calculators to incorporate additional details that have altered the treatment paradigm for spinal metastases, including minimally invasive techniques and focused radiosurgery. These predictors remain in their infancy, however, and as the field continues to develop them, we must remain cognizant of the fact that a nontrivial proportion of patients who do not meet the survival threshold will experience symptomatic benefit from surgery.

\section{References}

1. Pennington Z, Goodwin ML, Westbroek EM, et al. Lactate and cancer: spinal metastases and potential therapeutic targets (part 2). Ann Transl Med. 2019;7(10):221.

2. Chaichana KL, Woodworth GF, Sciubba DM, et al. Predictors of ambulatory function after decompressive surgery for metastatic epidural spinal cord compression. Neurosurgery. 2008;62(3):683-692.

3. Laufer I, Zuckerman SL, Bird JE, et al. Predicting neurologic recovery after surgery in patients with deficits secondary to MESCC: systematic review. Spine (Phila Pa 1976). 2016; 41(suppl 20):S224-S230.

4. Fisher CG, DiPaola CP, Ryken TC, et al. A novel classification system for spinal instability in neoplastic disease: an evidence-based approach and expert consensus from the Spine Oncology Study Group. Spine (Phila Pa 1976). 2010; 35(22):E1221-E1229.

5. Pennington Z, Ahmed AK, Westbroek EM, et al. SINS score and stability: evaluating the need for stabilization within the uncertain category. World Neurosurg. 2019;128:e1034-e1047.

6. Hussain I, Barzilai O, Reiner AS, et al. Spinal Instability Neoplastic Score component validation using patient-reported outcomes. J Neurosurg Spine. 2019;30(4):432-438.

7. Barzilai O, Versteeg AL, Sahgal A, et al. Survival, local control, and health-related quality of life in patients with oligometastatic and polymetastatic spinal tumors: a multicenter, international study. Cancer. 2019;125(5):770-778.

8. Depreitere B, Ricciardi F, Arts M, et al. How good are the outcomes of instrumented debulking operations for symptomatic spinal metastases and how long do they stand? A subgroup analysis in the Global Spine Tumor Study Group database. Acta Neurochir (Wien). 2020;162(4):943-950.

9. Horn SR, Dhillon ES, Poorman GW, et al. Epidemiology and national trends in prevalence and surgical management of metastatic spinal disease. J Clin Neurosci. 2018;53:183-187.

10. Yoshihara H, Yoneoka D. Trends in the surgical treatment for spinal metastasis and the in-hospital patient outcomes in the United States from 2000 to 2009. Spine J. 2014;14(9): 1844-1849.

11. Pennington Z, Ahmed AK, Molina CA, et al. Minimally invasive versus conventional spine surgery for vertebral metastases: a systematic review of the evidence. Ann Transl Med. 2018;6(6):103.

12. Luksanapruksa P, Buchowski JM, Hotchkiss W, et al. Prognostic factors in patients with spinal metastasis: a systematic review and meta-analysis. Spine J. 2017;17(5):689-708.

13. Cassidy JT, Baker JF, Lenehan B. The role of prognostic scoring systems in assessing surgical candidacy for patients 
with vertebral metastasis: a narrative review. Global Spine J. 2018;8(6):638-651.

14. Karhade AV, Thio QCBS, Ogink PT, et al. Predicting 90-day and 1-year mortality in spinal metastatic disease: development and internal validation. Neurosurgery. 2019;85(4): E671-E681.

15. Choi D, Pavlou M, Omar R, et al. A novel risk calculator to predict outcome after surgery for symptomatic spinal metastases; use of a large prospective patient database to personalise surgical management. Eur J Cancer. 2019;107:28-36.

16. Bilsky MH, Laufer I, Fourney DR, et al. Reliability analysis of the epidural spinal cord compression scale. J Neurosurg Spine. 2010;13(3):324-328.

17. Pennington $\mathrm{Z}$, Ahmed AK, Cottrill $\mathrm{E}$, et al. Intra- and interobserver reliability of the Spinal Instability Neoplastic Score system for instability in spine metastases: a systematic review and meta-analysis. Ann Transl Med. 2019;7(10):218.

18. Versteeg AL, van der Velden JM, Verkooijen HM, et al. The effect of introducing the Spinal Instability Neoplastic Score in routine clinical practice for patients with spinal metastases. Oncologist. 2016;21(1):95-101.

19. Quraishi NA, Arealis G, Salem KMI, et al. The surgical management of metastatic spinal tumors based on an Epidural Spinal Cord Compression (ESCC) scale. Spine J. 2015; 15(8):1738-1743.

20. Hussain I, Barzilai O, Reiner AS, et al. Patient-reported outcomes after surgical stabilization of spinal tumors: symptombased validation of the Spinal Instability Neoplastic Score (SINS) and surgery. Spine J. 2018;18(2):261-267.

21. Azad TD, Varshneya K, Ho AL, et al. Laminectomy versus corpectomy for spinal metastatic disease-complications, costs, and quality outcomes. World Neurosurg. 2019;131: e468-e473.

22. Luksanapruksa P, Buchowski JM, Zebala LP, et al. Perioperative complications of spinal metastases surgery. Clin Spine Surg. 2017;30(1):4-13.

23. De la Garza Ramos R, Goodwin CR, Jain A, et al. Development of a metastatic spinal tumor frailty index (MSTFI) using a nationwide database and its association with inpatient morbidity, mortality, and length of stay after spine surgery. World Neurosurg. 2016;95:548-555.e4.

24. Pennington Z, Pielkenrood B, Ahmed AK, et al. Visceral fat volume from standard preoperative $\mathrm{CT}$ is an independent predictor of short-term survival in patients undergoing surgery for metastatic spine disease. Clin Spine Surg. 2019; 32(6):E303-E310.

25. Bollen L, Jacobs WCH, Van der Linden YM, et al. A systematic review of prognostic factors predicting survival in patients with spinal bone metastases. Eur Spine J. 2018;27(4): 799-805.

26. Nater A, Martin AR, Sahgal A, et al. Symptomatic spinal metastasis: a systematic literature review of the preoperative prognostic factors for survival, neurological, functional and quality of life in surgically treated patients and methodological recommendations for prognostic studies. PLoS One. 2017; 12(2):e0171507.

27. Bourassa-Moreau É, Versteeg A, Moskven E, et al. Sarcopenia, but not frailty, predicts early mortality and adverse events after emergent surgery for metastatic disease of the spine. Spine J. 2020;20(1):22-31.

28. Tomita K, Kawahara N, Kobayashi T, et al. Surgical strategy for spinal metastases. Spine (Phila Pa 1976). 2001;26(3): 298-306.

29. Tokuhashi Y, Matsuzaki H, Toriyama S, et al. Scoring system for the preoperative evaluation of metastatic spine tumor prognosis. Spine (Phila Pa 1976). 1990;15(11):1110-1113.

30. Tokuhashi Y, Matsuzaki H, Oda H, et al. A revised scoring system for preoperative evaluation of metastatic spine tumor prognosis. Spine (Phila Pa 1976). 2005;30(19):2186-2191.
31. Choi D, Crockard A, Bunger C, et al. Review of metastatic spine tumour classification and indications for surgery: the consensus statement of the Global Spine Tumour Study Group. Eur Spine J. 2010;19(2):215-222.

32. Morgen SS, Fruergaard S, Gehrchen M, et al. A revision of the Tokuhashi revised score improves the prognostic ability in patients with metastatic spinal cord compression. J Cancer Res Clin Oncol. 2018;144(1):33-38.

33. Sioutos PJ, Arbit E, Meshulam CF, Galicich JH. Spinal metastases from solid tumors. Analysis of factors affecting survival. Cancer. 1995;76(8):1453-1459.

34. Rades D, Dunst J, Schild SE. The first score predicting overall survival in patients with metastatic spinal cord compression. Cancer. 2008;112(1):157-161.

35. van der Linden YM, Dijkstra SPDS, Vonk EJA, et al. Prediction of survival in patients with metastases in the spinal column: results based on a randomized trial of radiotherapy. Cancer. 2005;103(2):320-328.

36. Balain B, Jaiswal A, Trivedi JM, et al. The Oswestry Risk Index: an aid in the treatment of metastatic disease of the spine. Bone Joint J. 2013;95-B(2):210-216.

37. Bauer HCF, Wedin R. Survival after surgery for spinal and extremity metastases. Prognostication in 241 patients. Acta Orthop Scand. 1995;66(2):143-146.

38. Leithner A, Radl R, Gruber G, et al. Predictive value of seven preoperative prognostic scoring systems for spinal metastases. Eur Spine J. 2008;17(11):1488-1495.

39. Katagiri H, Takahashi M, Wakai K, et al. Prognostic factors and a scoring system for patients with skeletal metastasis. $J$ Bone Joint Surg Br. 2005;87(5):698-703.

40. Ahmed AK, Goodwin CR, Heravi A, et al. Predicting survival for metastatic spine disease: a comparison of nine scoring systems. Spine J. 2018;18(10):1804-1814.

41. Katagiri H, Okada R, Takagi T, et al. New prognostic factors and scoring system for patients with skeletal metastasis. Cancer Med. 2014;3(5):1359-1367.

42. Ghori AK, Leonard DA, Schoenfeld AJ, et al. Modeling 1-year survival after surgery on the metastatic spine. Spine $J$. 2015;15(11):2345-2350.

43. Schoenfeld AJ, Le HV, Marjoua Y, et al. Assessing the utility of a clinical prediction score regarding 30-day morbidity and mortality following metastatic spinal surgery: the New England Spinal Metastasis Score (NESMS). Spine J. 2016;16(4): 482-490.

44. Shi DD, Chen Y-H, Lam TC, et al. Assessing the utility of a prognostication model to predict 1-year mortality in patients undergoing radiation therapy for spinal metastases. Spine $J$. 2018;18(6):935-940.

45. Goodwin CR, Schoenfeld AJ, Abu-Bonsrah NA, et al. Reliability of a spinal metastasis prognostic score to model 1-year survival. Spine J. 2016;16(9):1102-1108.

46. Paulino Pereira NR, Janssen SJ, van Dijk E, et al. Development of a prognostic survival algorithm for patients with metastatic spine disease. J Bone Joint Surg Am. 2016;98(21): 1767-1776.

47. Paulino Pereira NR, Mclaughlin L, Janssen SJ, et al. The SORG nomogram accurately predicts 3 - and 12-months survival for operable spine metastatic disease: external validation. J Surg Oncol. 2017;115(8):1019-1027.

48. Karhade AV, Thio QCBS, Ogink PT, et al. Development of machine learning algorithms for prediction of 30-day mortality after surgery for spinal metastasis. Neurosurgery. 2019; 85(1):E83-E91.

49. Karhade AV, Ahmed AK, Pennington Z, et al. External validation of the SORG 90-day and 1-year machine learning algorithms for survival in spinal metastatic disease. Spine J. 2020;20(1):14-21.

50. Westermann L, Olivier AC, Samel C, et al. Analysis of seven prognostic scores in patients with surgically treated epidural 
metastatic spine disease. Acta Neurochir (Wien). 2020;162(1): 109-119.

51. Dea N, Versteeg AL, Sahgal A, et al. Metastatic spine disease: should patients with short life expectancy be denied surgical care? An international retrospective cohort study. Neurosurgery. 2020;87(2):303-311.

52. Bünger C, Laursen M, Hansen ES, et al. A new algorithm for the surgical treatment of spinal metastases. Curr Opin Orthop. 1999;10(2):101-105.

53. Kwan MK, Lee CK, Chan CYW. Minimally invasive spinal stabilization using fluoroscopic-guided percutaneous screws as a form of palliative surgery in patients with spinal metastasis. Asian Spine J. 2016;10(1):99-110.

54. Laufer I, Bilsky MH. Advances in the treatment of metastatic spine tumors: the future is not what it used to be. J Neurosurg Spine . 2019;30(3):299-307.

55. Pennington Z, Sciubba DM. Commentary: Predicting 90-day and 1-year mortality in spinal metastatic disease: development and internal validation. Neurosurgery. 2019;85(4): E682-E683.

56. Hoskin PJ, Hopkins K, Misra V, et al. Effect of singlefraction vs multifraction radiotherapy on ambulatory status among patients with spinal canal compression from metastatic cancer: the SCORAD Randomized Clinical Trial. JAMA. 2019;322(21):2084-2094.

57. Hibberd CS, Quan GMY. Accuracy of preoperative scoring systems for the prognostication and treatment of patients with spinal metastases. Int Sch Res Notices. 2017;2017:1320684.

58. Majeed H, Kumar S, Bommireddy R, et al. Accuracy of prognostic scores in decision making and predicting outcomes in metastatic spine disease. Ann R Coll Surg Engl. 2012;94(1): $28-33$.
59. Wibmer C, Leithner A, Hofmann G, et al. Survival analysis of 254 patients after manifestation of spinal metastases: evaluation of seven preoperative scoring systems. Spine (Phila Pa 1976). 2011;36(23):1977-1986.

60. Bollen L, van der Linden YM, Pondaag W, et al. Prognostic factors associated with survival in patients with symptomatic spinal bone metastases: a retrospective cohort study of 1,043 patients. Neuro Oncol. 2014;16(7):991-998.

\section{Disclosures}

Mr. Cottrill: F30 grant from National Institutes on Aging. Dr. Sciubba: consultant for Baxter, DePuy-Synthes, Globus Medical, K2M, Medtronic, NuVasive, and Stryker; unrelated grant support from Baxter Medical, North American Spine Society, and Stryker.

\section{Author Contributions}

Conception and design: Pennington. Acquisition of data: Pennington. Analysis and interpretation of data: Pennington. Drafting the article: Pennington, Ehresman, Cottrill, Lubelski. Critically revising the article: Pennington, Ehresman, Cottrill, Lubelski, Lehner, Feghali, Ahmed, Schilling. Reviewed submitted version of manuscript: all authors. Approved the final version of the manuscript on behalf of all authors: Sciubba.

\section{Correspondence}

Daniel M. Sciubba: Johns Hopkins University School of Medicine, Baltimore, MD. dsciubb1@jhmi.edu. 